\title{
Incidence of cardiopulmonary arrests after implementation of a rapid response system during operation time vs non-operation time
}

\author{
YY Choi", J Min, DS Lee, H Min, EY Lee, G Lim, Y Kim, H Kang, I Song, Y -J Cho, YJ Lee \\ From ESICM LIVES 2015 \\ Berlin, Germany. 3-7 October 2015
}

\section{Introduction}

Rapid response systems (RRSs) are considered an important tool for improving patient safety.

\section{Objectives}

We studied the effect of an RRS on the incidence of cardio-pulmonary arrests (CPAs).

\section{Methods}

We performed a retrospective before-after analysis of the CPAs in a 1,360-bed tertiary care hospital from January, 2009 to October, 2014. We included 176,193 admissions before and 117,822 admissions after implementing the RRS on October, 2012. The operation time of the RRS was from 7 am to $10 \mathrm{pm}$ during weekdays. The primary outcome was CPA incidence, which was expressed as the case per 1,000 admissions.

\section{Results}

The overall CPA incidence was 1.31. Although the number of admission per month and the case-mix index were increased (3915.4 vs. 4712.9, $\mathrm{p}=<0.001 ; 1.0923$ vs. 1.1255 , $\mathrm{p}=0.003$, respectively), the CPA incidence was significantly decreased (1.66 vs. $1.25, \mathrm{p}=0.03$ ), and there was no detectable changes on the mortality (1.27 vs. 1.33 , $\mathrm{p}=0.273$ ). The CPA incidence in the surgical department was significantly reduced ( 1.13 vs. $0.38, \mathrm{p}=0.014)$, however, the reduction of the CPA incidence in the medical department was insignificant (3.93 vs. 2.97, $\mathrm{p}=0.075$ ). The implementation of the RRS did not reduce the CPA incidence during non-operation time $(0.80$ vs. 0.73 , $\mathrm{p}=0.573)$, but decreased during operation time ( $0.86 \mathrm{vs}$. $0.52, \mathrm{p}=0.001)$. The immediate survival rate $(76.9 \% \mathrm{vs}$.

Seoul National University Bundang Hospital, Seongnam, Republic ofKorea
$67.2 \%, \mathrm{p}=0.034$ ) during the operation hours of the RRSs was better than during the non-operation hours.

\section{Conclusions}

The implementation of the RRS reduced the CPA incidence, which was originated in the reduction of the CPA during the operation hours.

Published: 1 October 2015

doi:10.1186/2197-425X-3-S1-A527

Cite this article as: Choi et al:: Incidence of cardiopulmonary arrests after implementation of a rapid response system during operation time vs non-operation time. Intensive Care Medicine Experimental 2015 3(Suppl 1):A527.

\section{SpringerOpen ${ }^{\circ}$}

(C) 2015 Choi et al.; This is an Open Access article distributed under the terms of the Creative Commons Attribution License (http:// creativecommons.org/licenses/by/4.0), which permits unrestricted use, distribution, and reproduction in any medium, provided the original work is properly cited.
Submit your manuscript to a SpringerOpen ${ }^{\circ}$ journal and benefit from:

- Convenient online submission

- Rigorous peer review

- Immediate publication on acceptance

- Open access: articles freely available online

- High visibility within the field

- Retaining the copyright to your article

Submit your next manuscript at $>$ springeropen.com 